\title{
MODEL PERBAIKAN INTERAKSI HUMANIS PETUGAS DENGAN NARAPIDANA SEBAGAI PARADIGMA BARU DALAM UPAYA PENCEGAHAN TINDAK PIDANA DALAM LEMBAGA PEMASYARAKATAN
}

\author{
Umi Enggarsasi \\ Sudahnan \\ Fakultas Hukum Universitas Wijaya Kusuma Surabaya \\ e-mail: enggarsasi.umi@gmail.com,sudah_nan66@yahoo.com
}

\begin{abstract}
ABSTRAK
Sistem pemasyarakatan diatur dalam Pasal 2 UU No. 12 Tahun 1995 tentang Pemasyarakatan yang menegaskan bahwa tujuan pembinaan untuk membentuk Warga Binaan Pemasyarakatan menjadi manusia seutuhnya, menyadari kesalahan, memperbaiki diri dan tidak mengulangi tindak pidana lagi, sehingga diterima kembali di lingkungan masyarakat, dapat aktif berperan dalam membangun dan dapat hidup secara wajar. Pembinaan terhadap narapidana di Lembaga Pemasyarakatan keberhasilannya tergantung pada unsur struktur, substansi hukum, kultur yang ada di dalamnya, yang tercermin dalam keterpaduan petugas Lembaga Pemasyarakatan, narapidana dan masyarakat atau keluarga. Kenyataannya di dalam Lembaga Pemasyarakatan masih sering terjadinya perkelahian, penganiayaan bahkan ada pembunuhan di dalam Lembaga Pemasyarakatan juga masih banyaknya residivis.
\end{abstract}

Kata Kunci: interaksi humanis, pembinaan narapidana, paradigma baru.

\section{ABSTRACT}

Social system set forth in article 2 of Act No. 12 of 1995 concerning Corrections, which confirms that the purpose of the coaching is to form the citizen in our prisons become fully human, aware of the mistakes, improve themselves and not repeat the crime anymore, so may be welcomed back in the environment of the community, can be actively involved in building, and are able to live reasonably. Coaching against inmates in Correctional Institutions is its success depends on structural elements, the substance of the law, culture in it, which is reflected in the Correctional Officer alignment, prisoners, and community or family. The reality in the Penitentiary Institutions are still frequent fights, abuse, even murder in the correctional facility, is also still the number recidivists.

Keyword: social system, interaction, structural elements.

\section{PENDAHULUAN}

Penelitian yang pernah penulis lakukan berkaitan dengan narapidana yaitu tentang mantan narapidana yang menghasilkan temuan bahwa pola pembinaan narapidana dalam memberikan kontribusi kurang berhasil karena kurangnya sarana dan prasarana sebagaimana diamanatkan oleh UU No. 12 Tahun 1995 tentang Pemasyarakatan, Penerimaan masyarakat dan perlakuan terhadap mantan narapidana dapat menentukan keberhasilan pembinaan. Komunikasi yang efektif antara warga Yayasan Majapahit tanpa memperdulikan statusnya akan menunjang keberhasilan proses pembinaan, program konseling yang biasa dilakukan setiap saat oleh mantan narapidana dengan keterbukaan akan memperlancar proses komunikasi.

Sistem Permasyarakatan sebagaimana diatur dalam Pasal 2 UU No. 12 Tahun 1995 tentang Pemasyarakatan menyebutkan bahwa tujuan pembinaan untuk membentuk warga binaan pemasyarakatan menjadi manusia seutuhnya, menyadari kesalahan, memperbaiki diri dan tidak mengulangi tindak pidana lagi sehingga diterima kembali di lingkungan masyarakat, dapat aktif berperan dalam pembangunan, dan dapat hidup 
secara wajar. Fungsi sistem pemasyarakatan adalah menyiapkan warga binaan Pemasyarakatan agar dapat berinteraksi secara baik dengan masyarakat, sehingga dapat berperan kembali sebagai anggota masyarakat yang bebas dan bertanggungjawab. Sasaran pembinaan dan pembimbingan warga binaan pemasyarakatan adalah meningkatkan kualitas warga binaan pemasyarakatan yang terjadi awalnya sebagian atau seluruhnya dalam kondisi kurang yaitu dalam hal kualitas ketaqwaan kepada Tuhan Yang Maha Esa, kualitas intelektual, kualitas sikap dan perilaku, kualitas profesionalitas/keterampilan, dan kualitas kesehatan jasmani dan rohani.

Keberhasilan pembinaan narapidana ditentukan oleh terpadunya faktor petugas Lapas, narapidana, dan masyarakat. Usaha pembinaan narapidana diarahkan untuk mencapai sasaran akhir yaitu berinteraksi dengan masyarakat, artinya masyarakat ikut pula terlibat dalam proses pembinaan narapidana. Mendasarkan pada pendapat Soedjono Dirdjosisworo, yang menyatakan bahwa Lapas berada di tengahtengah masyarakat, dan narapidana, sedangkan narapidana berasal dari masyarakat, dan petugas pembina Lapas juga berasal dari masyarakat, oleh sebab itu keterpaduan ketiga unsur tersebut sangat penting. Oleh karena itu apabila ketiga unsur tersebut berfungsi dengan baik yaitu Lapas cukup memenuhi syarat sesuai Undang-Undang Nomor 12 Tahun 1995 tentang Pemasyarakatan, narapidana menyadari hak dan kewajibannya (mudah dibina) dan petugas pembina mempunyai kualitas yang mampu melaksanakan kewajibannya dan sebagai sasaran akhir masyarakat menerima kembali mantan narapidana sebagai warga masyarakat secara utuh, maka tujuan pemidanaan akan tercapai sesuai amanat UU No. 12 Tahun 1995 tentang Pemasyarakatan.

Pentingnya peran Lembagas Pemasyarakatan (yang selanjutnya disebut Lapas) dalam sistem peradilan pidana yang menyeluruh atau Integrated Criminal Justice Sistem ${ }^{1}$ disebabkan Lapas adalah salah satu sub sistem dari sub sistem-sub sistem lain seperti Kepolisian, Kejaksaan, dan Pengadilan. Kepolisian adalah instansi pertama dari otoritas sistem peradilan pidana yang pertama menjalin kontak dengan pelaku kejahatan. Dalam suasana yang demikian, polisi sesungguhnya bukan hanya berhadapan dengan persoalan hukum pidana saja,

1 Soemadipraja dan Romli Atmasasmita, Sistem Pemasyarakatan di Indonesia, Bina Cipta, Bandung, 1979, h. 20. tetapi juga menyangkut persoalan pelaku kejahatan sebagai manusia dengan segala kepribadiannya. Pada bagian ini seyogyanya lembaga kepolisian mencoba menseleksi setiap tindak pidana yang dilakukan apakah layak diteruskan ketahapan selanjutnya atau cukup diselesaikan di tingkat penyidikan di samping memperlakukan pelaku kejahatan secara manusiawi.

Tindakan polisi dan penuntut umum untuk memproses perkara tidak boleh merendahkan martabat atau merugikan pelaku kejahatan. ${ }^{2}$ Pengadilan sebagai lembaga yang bertugas menjatuhkan atau memberikan sanksi pidana yang dijatuhkan tersebut dapat membawa dampak positif bagi narapidana tersebut. Jadi, persoalannya adalah bahwa penjatuhan sanksi pidana bukan hanya sekedar berat ringannya sanksi pidana, akan tetapi pemberian sanksi pidana itu harus sesuai dengan nilai-nilai sosial, budaya dan struktur yang hidup dalam masyarakat, yang pada gilirannya proses pemidanaan akan membawa dampak positif terhadap proses pembinaan narapidana. Tujuannya agar terjadi kesesuaian antara realita hukum dan undang-undang serta realita pelaksanaan hukum sehari-hari.

Lapas sebagai lembaga koreksi merupakan faktor penentu keberhasilan sistem peradilan pidana terpadu. ${ }^{3}$ Proses pembinaan di Lapas menjadi tempat penggodokan sampai pada kriteria tertentu hingga sampai pada pengembalian ke dalam masyarakat, jadi pemidanaan dikhususkan pada pembinaan narapidana dan sekaligus pengayoman terhadap masyarakat atau Treatment of Society and Treatment of Offenders.

Kenyataannya interaksi antara narapidana dan petugas pembina di Lapas tidak berjalan dengan baik sehingga menimbulkan gejolak di dalam Lapas sebagai contoh yang terjadi dalam Lapas di Denpasar. Kasus kerusuhan di Lapas Denpasar, merupakan bukti disinteraksi antara narapidana dan petugas Lapas. Menarik pula untuk diketahui tentang kehidupan narapidana di Lapas. Kompasianer Hsu mencirikan Lapas merupakan sebuah kerajaan dengan pengorganisasian napi supaya berjalan sempurna hingga melakukan pergerakan sebagaimana yang terjadi di Lapas Tanjung Gusta Medan yaitu kebakaran yang berulangkali baik karena hubungan arus pendek maupun disengaja oleh napi. Dampaknya pada $12 \mathrm{Juli}$ 2013 Lapas Tanjung Gusta dibakar dengan korban 2

\footnotetext{
${ }^{2}$ Ibid., h. 8

${ }^{3}$ Muladi, Kapita Selekta Sistem Peradilan, Badan Penerbit UNDIP, Semarang, 1995, h. vii.
} 
petugas dan 3 narapidana meninggal serta 150 napi kabur termasuk napi teroris dari Lapas. ${ }^{4}$ Menurut Wahyu Wagiman dari Working Group Against Tecture (WGAT) bahwa kurun waktu Desember 2011 sampai Februari 2012 mencatat sembilan kasus kematian tahanan dan narapidana di tempat-tempat penahanan bahkan, menurut catatan Polri sepanjang tahun 2011 jumlah tahanan yang meninggal di beberapa rumah tahanan di Indonesia sebanyak 19 orang, dan penyebab meninggalnya tahanan dan narapidana ada proses di Kepolisian maupun Lapas antara lain karena perkelahian sesama tahanan dan dugaan penyiksaan oleh petugas. ${ }^{5}$

Berdasarkan pengamatan Kepala Kepolisian Daerah Bali, Irjen Polisi Totok Herawan Indra, bahwa kerusuhan di Lapas Kerobokan Denpasar dipicu oleh kekecewaan narapidana yang diperlakukan diskriminatif oleh petugas Lapas. ${ }^{6}$

Berkaitan dengan kondisi Lapas yang ada penting dilakukan penelitian tentang Model Perbaikan Interaksi Humanis Petugas dengan Narapidana sebagai Paradigma Baru dalam Upaya Pencegahan Tindak Pidana dalam Lapas di Jawa Timur, mengingat di Jawa Timur ada 38 Rumah Tahanan dan Lapas yang terdiri dari 24 Lapas dan 13 Rutan serta 1 Cabang Rutan. Keberadaan Rumah Tahanan dan Lapas yang tersebar di Jawa Timur tersebut yang ditempati dari sejumlah penghuni tahanan dan napi yang tidak sebanding dengan kapasitas Lapas dan Rutan itu sendiri, sehingga menyebabkan kelebihan penghuni dari kapasitas yang sebenarnya pada Lapas dan Rutan tertentu dan kekurangan penghuni dari kapasitas yang sebenarnya pada Lapas dan Rutan tertentu, sebagaimana Data Tabel terhadap jumlah penghuni Tahanan dan Napi per-UPT pada Kanwil Jawa Timur pada bulan April tahun 2014 yang menunjukkan ada 27 Lapas dan Rutan yang kelebihan penghuni dari kapasitas Lapas dan Rutan itu sendiri dan hanya ada 10 Lapas dan Rutan yang masih sebanding dari kapasitas Lapas dan Rutan itu sendiri, ${ }^{7}$ sebagai contoh perbandingan Lapas Kelas I Madiun, jumlah penghuni per April 2014 sebanyak 1.330 sedangkan kapasitas Lapas hanya dapat dihuni

\footnotetext{
${ }^{4}$ Tribunews.com, Jakarta, diakses tanggal 11 Juli 2013.

${ }^{5}$ Yulis Setiawan, tribunnews.com, diakses tanggal 3 Maret 2012.

${ }^{6}$ Antara News, diakses tanggal 22 Februari 2012. 2012
}

sebanyak 536 sangat jauh sekali sekitar tiga kali lipat banyaknya penghuni dengan tempatnya, Rutan Kelas 1 Surabaya, jumlah penghuni per April 2014 sebanyak 1.675 sedangkan kapasitas Rutan hanya dapat dihuni sebanyak 204 sangat jauh sekali sekitar lima belas kali lipat banyaknya penghuni dengan tempatnya. Kalau dihitung dari jumlah penghuni dari Lapas dan Rutan yang ada di Jawa Timur sebanyak 38 Lapas dan Rutan dengan jumlah kapasitas kamar atau tempat tidur seluruhnya 11.778 sedangkan keberadaan penghuni Lapas dan Rutan sebanyak 16.357, dari data tersebut per April 2014 Lapas yang paling banyak penghuni napi terjadi pada Lapas Kelas 1 Malang dengan jumlah penghuni sebanyak 1908 orang sedangkan Lapas yang terendah penghuni napi terjadi pada Rutan Kelas II B Madiun sebanyak 89 orang.

Apabila mengamati data tersebut dapat dipastikan bahwa Rutan atau Lapas yang ada di JawaTimur mengalami kelebihan kapasitas hunian, yang berpotensi terjadi tindak pidana dalam Lapas sehingga sangat diperlukan kemampuan petugas Lapas untuk mengendalikan kondisi yang ada dalam Lapas.

\section{PERUMUSAN MASALAH}

Berdasarkan kondisi tersebut maka permasalahan yang dirumuskan sebagai berikut: 1. Bagaimana pengaturan sistem pembinaan narapidana berdasarkan UU No. 12 Tahun 1995 tentang Pemasyarakatan dan PP No. 31 Tahun 1999 tentang Pembinaan dan Pembimbingan Warga Binaan Pemasyarakatan? 2. Kendala yang dihadapi petugas Lapas untuk membentuk kepatuhan hukum narapidana dalam Lapas; 3. Model interaksi humanis petugas Lapas dengan narapidana sebagai paradigma baru dalam upaya pencegahan terjadinya tindak pidana dalam Lapas.

\section{METODE PENELITIAN}

Penelitian ini dengan pendekatan yuridis sosiologis (empiris), dengan data primer dan sekunder, dan analisa secara kualitatif dan disajikan secara deskriptif. Penelitian dilakukan di beberapa Lapas di Jawa Timur, antara lain: Lapas Kelas II B Lamongan, Lapas Kelas II B Tuban, Lapas Kelas II A Sidoarjo, Lapas Kelas II B Mojokerto, Lapas Kelas II B Jombang, Lapas Kelas II A Pamekasan, Rutan Kelas II B Sampang.

Metode kualitatif, karena apabila menemukan kenyataan atau fakta yang ganda, penyesuaian metode 
kualitatif lebih mudah dilakukan. Menyajikan secara langsung hakekat hubungan antara peneliti dengan responden, lebih peka, dan lebih mudah menyesuaikan diri dengan banyak penajaman pengaruh bersama atas pola-pola, nilai-nilai yang dihadapi di lapangan (Le Moleong, 1996:6).

Deskripsi data hasil penelitian menggambarkan interaksi antara narapidana dan petugas Lembaga Pemasyarakatan di Jawa Timur.

\section{PEMBAHASAN}

Sistem Pembinaan Narapidana Berdasarkan UU No. 12 Tahun 45 tentang Pemasyarakatan dan PP No. 31 Tahun 1999 tentang Pembinaan dan Pembimbingan Warga Binaan Pemasyarakatan

Pembinaan terhadap narapidana disesuaikan dengan asas-asas yang terkandung dalam Pancasila, Undang-Undang Dasar 1945, Standar Minimum Rules (SMR) yang tercermin dalam 10 Prinsip Pemasyarakatan, selain itu mengacu pada: pertama, Undang-undang Nomor 12 Tahun 1995 tentang Pemasyarakatan; kedua, Surat Keputusan Menteri Kehakiman R.I. Nomor: M.02-PK.04.10 Tahun 1999 tentang Asimilasi, Pembebasan Bersyarat, Cuti Menjelang Bebas; ketiga, Peraturan Pemerintah Nomor 31 Tahun 1999 tentang Pembinaan dan Pembimbingan Warga Binaan Pemasyarakatan; keempat, Peraturan Pemerintah Nomor 32 Tahun 1999 tentang Syarat dan Tata Cara Pelaksanaan Hak Warga Binaan Pemasyarakataan; kelima, Peraturan Pemerintah R.I. Nomor 57 Tahun 1999 tentang Kerja Sama Penyelenggaraan Pembinaan dan Pembimbingan Warga Binaan Pemasyarakatan; keenam, Keputusan Menteri Kehakiman R.I. Nomor M.02-PK.04.10 Tahun 1990 tentang Pola Pembinaan Narapidana/Tahanan.

Fungsi dan tugas pembinaan pemasyarakatan terhadap narapidana dilaksanakan secara terpadu dengan tujuan agar mereka setelah selesai melaksanakan hukumannya termasuk didalamnya proses pembinaan dapat menjadi warga masyarakat yang baik.

Setelah keluarnya UU No. 12 Tahun 1995, pembinan narapidana diatur dalam Peraturan Pemerintah Nomor 31 Tahun 1999 (selanjutnya disebut PP No. 31 Tahun 1999) dalam Pasal 7 ayat (2), bahwa pembinaan narapidana terdiri atas 3 (tiga) tahap yaitu: Tahap awal, Tahap lanjutan, dan Tahap akhir.
Dalam Pasal 9 ayat (1, 2 dan 3) PP No. 31 Tahun 1999 dijelaskan tentang tahap-tahap pembinaan tersebut. Pembinaan tahap awal dimulai sejak yang bersangkutan berstatus sebagai narapidana sampai dengan $1 / 3$ dari masa pidana. Selanjutnya pembinaan tahap lanjutan meliputi: 1. Tahap lanjutan pertama, sejak berakhirnya pembinaan tahap awal sampai dengan $1 / 2$ dari masa pidana; 2 . Tahap lanjutan kedua, sejak berakhirnya pembinaan tahap lanjutan pertama sampai dengan $2 / 3$ masa pidana.

Pembinaan tahap akhir dilaksanakan sejak berakhirnya tahap lanjutan sampai dengan berakhirnya masa pidana dari narapidana yang bersangkutan. Bagi narapidana yang dipidana penjara seumur hidup tidak dilakukan pentahapan sebagaimana tersebut di atas. Menurut Pasal 10 PP No. 31 Tahun 1999 bahwa: Pertama, Pembinaan tahap awal sebagaimana dimaksud dalam Pasal 9 ayat (1) meliputi: Masa pengamatan, pengenalan dan penelitian lingkungan paling lama 1 (satu) bulan; Perencanaan program pembinaan kepribadian dan kemandirian; Pelaksanaan program pembinaan kepribadian dan kemandirian; dan Penilaian pelaksanaan program pembinaan tahap awal. Kedua, Pembinaan tahap lanjutan meliputi: Perencanaan program pembinaan lanjutan; Pelaksanaan program pembinaan lanjutan; Penilaian pelaksanaan program pembinaan lanjutan dan; Perencanaan dan pelaksanaan program asimilasi. Ketiga, Pembinaan tahap akhir, meliputi: Perencanaan program integrasi; Pelaksanaan program integrasi dan; Pengakhiran pelaksanaan pembinaan tahap akhir. Keempat, Pentahapan pembinaan sebagaimana dimaksud dalam ayat (1), ayat (2) dan ayat (3) ditetapkan melalui sidang Tim Pengamat Pemasyarakatan. Kelima, Dalam sidang Tim Pengamat Pemasyarakatan, Kepala Lapas wajib memperhatikan hasil lintas.

Sehubungan dengan itu dalam Pasal 11 PP No. 31 Tahun 1999 menegaskan bahwa: Pembinaan tahap awal dan tahap lanjutan dilaksanakan di Lapas, dan Pembinaan tahap akhir dilaksanakan di luar Lapas oleh BAPAS, serta dalam hal narapidana tidak memenuhi syarat-syarat tertentu pembinaan tahap akhir narapidana yang bersangkutan tetap dilaksanakan di Lapas.

Penjelasan umum UU No. 12 Tahun 1995 yang merupakan dasar yuridis filosofi tentang pelaksanaan sistem pemasyarakatan di Indonesia dinyatakan bahwa: 
Pertama, Bahwa Negara Indonesia yang berdasarkan Pancasila, pemikiran-pemikiran baru mengenai fungsi pemidanaan tidak lagi sekedar penjeraan tetapi juga merupakan suatu usaha rehabilitasi dan reintegrasi sosial Warga Binaan Pemasyarakatan telah melahirkan suatu sistem pembinaan yang sejak lebih dari tiga puluh tahun yang dikenal dan dinamakan sistem pemasyarakatan.

Kedua, Walaupun telah diadakan berbagai perbaikan mengenai tatanan atau stelsel pemidanaan seperti pranata pidana bersyarat (Pasal 14a KUHP), pelepasan bersyarat (Pasal 15 KUHP), dan pranata khusus penentuan serta penghukuman terhadap anak (Pasal 77 sampai dengan Pasal 90 UndangUndang No. 23 Tahun 2002 tentang Perlindungan Anak). Namun pada dasarnya sifat pembinaan masih bertolak dari asas dan sistem pemenjaraan. Sistem pemenjaraan sangat menekankan pada unsur balas dendam dan penjaraan, sehingga institusi yang dipergunakan sebagai tempat pembinaan adalah rumah penjara bagi narapidana dan rumah pendidikan negara bagi anak yang bersalah.

Ketiga, Sistem pemenjaraan yang sangat menekankan pada unsur balas dendam dan penjeraan yang disertai dengan lembaga "rumah penjara" secara berangsur-angsur di pandang sebagai suatu sistem dan sarana yang tidak sejalan dengan konsep rehabilitasi dan reintegrasi sosial, agar narapidana menyadari kesalahannya, tidak lagi berkehendak untuk melakukan tindak pidana dan kembali menjadi warga masyarakat yang bertanggungjawab bagi diri, keluarga, dan lingkungannya.

Dari penjelasan umum tersebut, jelas bahwa fungsi pemidanaan untuk melakukan rehabilitasi dan reintegrasi sosial agar narapidana menyadari kesalahannya dan memperbaiki diri sehingga dapat kembali menjadi warga masyarakat yang baik dan berguna.

Lapas sebagai ujung tombak pelaksanaan asas pengayoman merupakan tempat untuk mencapai tujuan pembinaan melalui pendidikan, rehabilitasi, dan reintegrasi. Sejalan dengan peran Lapas tersebut, maka petugas Lapas yang melaksanakan tugas pembinaan, pengamanan, pembimbingan, dan sebagai Pejabat Fungsional Penegak Hukum.

Sistem pemasyarakatan bertujuan untuk mengembalikan Warga Binaan Pemasyarakatan sebagai warga yang baik juga bertujuan untuk melindungi masyarakat terhadap kemungkinan diulanginya tindak pidana oleh Warga Binaan Pemasyarakatan, serta merupakan penerapan dan bagian yang tak terpisahkan dari nilai-nilai yang terkandung dalam Pancasila. Sistem pemasyarakatan Indonesia lebih menekankan kepada aspek pembinaan Narapidana. Anak Didik Pemasyarakatan, atau Klien Pemasyarakatan yang mempunyai nilai-nilai preventif, kuratif, rehabilitatif, dan edukatif.

Fungsi Lapas sebagai lembaga pendidikan dan sekaligus sebagai lembaga pembangunan yang mampu meningkatkan nilai tambah bagi narapidana, dengan mempertajam program pembinaan narapidana (warga binaan masyarakat). Contohnya dengan meningkatkan bobot keterampilan, melatih kemandirian narapidana meningkatkan produktifitas hasil kerja yang semuanya tiada lain untuk pembekalan diri baik mental, spiritual, menjelang kembali ke masyarakat. Dengan kata lain Lapas sebagai wadah pembinaan narapidana harus mampu berfungsi sebagai lembaga pendidikan dan pembangunan. ${ }^{8}$

Peran ganda Lapas, baik sebagai lembaga pendidikan dan lembaga pembangunan, tertuang dalam kebijaksanaan Departemen Kehakiman R.I. yang tertuang dalam keputusan Menteri Kehakiman R.I. No. M.02-PK.04.10 Tahun 1990 tentang Pola Pembinaan Narapidana/Tahanan, yang antara lain menegaskan sebagai berikut: Dengan dasar memikiran tersebut, maka konsep pemasyarakatan, pada hakikatnya adalah juga pemasyarakatan Pancasila yang turut berperan dalam pembangunan sehingga ia pun merupakan salah satu lembaga pendidikan dan lembaga pembangunan.

Untuk mencapai tujuan pembinaan narapidana perlu dikembangkan pemasyarakatan yang terbuka dan produktif yang bertujuan turut menggiatkan kegiatan-kegiatan sosial ekonomi, untuk kepentingan mereka sendiri dan untuk kepentingan pembangunan.

Fungsi pemasyarakatan terbuka dan produktif yang disingkat pemasyarakatan terbuka adalah: Lembaga pendidikan yang mendidik manusia narapidana dalam rangka terciptanya kualitas manusia, Lembaga pembangunan yang mengikutsertakan manusia narapida menjadi manusia pembangunan produktif. $^{9}$

\footnotetext{
${ }^{8}$ Adi Sujatno, “Upaya-upaya Menuju Pelaksanaan Lembaga Pemasyarakatan Terbuka di Lapas Kelas I Jawa Timur", Makalah, Disampaikan pada Seminar Nasional Pemasyarakatan Terpidana II, tgl. 8-9 Nopember 1993, FH UI, h. 13.

${ }^{9}$ Ibid., h. 5.
} 
Dengan ciri-ciri tersebut maka Lapas bukan saja sudah harus berubah dalam pola pembinaan yang dilakukan, tetapi sekaligus juga sudah harus merubah orientasinya dari lembaga konsumtif menjadi lembaga produktif.

Sebagaimana telah dikemukakan sebelumnya, Saharjo yang mempunyai ide untuk melakukan pembaharuan atau perbaikkan terhadap hukum yang berlaku pada saat itu dan dituangkan dalam pidato pengukuhan pada saat menerima gelar Doctor Honoris Causa dari Universitas Indonesia tahun 1963, dengan judul "Pohon Beringin Pengayoman", yang secara langsung menyangkut nasib narapidana di dalam penjara.

Menurut Adi Suyatno, ide dasar dan gagasangagasan tersebut antara lain, Pohon beringin pengayoman sebagai lambang hukum di Indonesia, dan Tugas hukum ialah memberi pengayoman agar cita-cita luhur bangsa tercapai dan terpelihara, serta di bawah pohon beringin pengayoman tidak saja masyarakat diayomi terhadap diulanginya perbuatan jahat oleh terpidana melainkan juga orang yang telah tersesat diayomi dengan memberikan kepadanya bekal hidup sebagai warga yang berguna di dalam masyarakat. ${ }^{10}$

Dalam Pasal 5 UU No. 12 Tahun 1995 tentang Pemasyarakatan disebutkan bahwa Sistem Pembinaan Pemasyarakatan dilaksanakan berdasarkan asas: Pengayoman; Persamaan perlakuan dan pelayanan; Pendidikan; Pembimbingan; Penghormatan harkat dan martabat manusia; Kehilangan kemerdekaan merupakan satu-satunya penderitaan, Terjaminnya hak untuk tetap berhubungan dengan keluarga orangorang tertentu.

Menurut Patta Parang, pengertian asas pengayoman ialah dengan melakukan pembinaan masyarakat terlindung dari kemungkinan dilakukannya kembali tindak pidana oleh warga binaan, juga memberikan bekal hidup berupa keterampilan agar bisa menjadi warga yang berguna di dalam masyarakat. Jadi dengan asas ini baik masyarakat maupun warga binaan terayomi. ${ }^{11}$

Pengertian asas persamaan perlakuan dan pelayanan ialah, memberikan perlakuan dan pelayanan yang sama kepada semua warga binaan

\footnotetext{
${ }^{10}$ Ibid., h. 5.

${ }^{11}$ Patta Parang, "Peran Aktif Petugas Lembaga Pemasyarakatan dalam Membina Narapidana”, Tesis, Program Studi Ilmu Hukum Program Pasca Sarjana UI, Jakarta, 1997, h. 61-64
}

dengan tidak membeda-bedakan orang. Hal ini berarti bahwa dalam hal binaan tidak ada perbedaan antara orang yang miskin dengan yang kaya, tidak ada perbedaan antara orang biasa dengan bekas pejabat. Mereka akan mendapatkan hak yang sama umpamanya dalam hal pembebasan bersyarat kalau persyaratan untuk itu telah dipenuhi.

"Asas pendidikan dan bimbingan" ialah bahwa pendidikan dan bimbingan berdasarkan Pancasila. Karena itu pendidikan dan bimbingan dilakukan untuk menanamkan kesadaran bermasyarakat, berbangsa dan bernegara, kesadaran beragama serta pendidikan keterampilan.

Pengertian dari "asas penghormatan harkat dan martabat manusia" adalah bahwa walaupun warga binaan itu sebagai orang yang tersesat, mereka tidak boleh dihina, dibentak atau diberi pekerjaan yang kurang wajar dan lain-lain.

Sedangkan pengertian "asas kehilangan kemerdekaan merupakan satu-satunya penderitaan" ialah warga binaan harus berada dalam lapas untuk jangka waktu tertentu, sehingga Negara mempunyai kesempatan penuh untuk memperbaikinya.Selama mereka dalam lembaga pemasyarakatan tetap dilindungi seperti memperolah perawatan kesehatan, makanan, minuman, pakaian, tempat tidur, latihan keterampilan, berolahraga dan lain-lain.

Kemudian pengertian dengan asas "terjaminnya hak untuk tetap berhubungan dengan keluarga dan orang-orang tertentu" ialah bahwa walaupun mereka berada di dalam lembaga pemasyarakatan, tetapi harus tetap didekatkan dan dikenalkan dengan masyarakat dan tidak boleh diasingkan dari padanya, umpamanya berhubungan dengan masyarakat dalam bentuk kunjungan, hiburan ke dalam Lapas dari anggota masyarakat yang bebas, kesempatan berkumpul dengan keluarga, juga dengan orang lain seperti pemuka agama, pangacara dan lain-lain.

Mengenai pedoman pelaksana pembinaan yang dilakukan di dalam Lapas, diatur dalam Pasal 10 UU No. 12 Tahun 1995 menegaskan bahwa Terpidana yang diterima di Lapas wajib didaftar, dan Pendaftaran mengubah status terpidana menjadi narapidana, serta Kepala Lapas bertanggungjawab atas penerimaan terpidana dan pembebasan narapidana di Lapas.

Penetapan terpidana di Lapas dilakukan sesuai dengan Pasal 270 Kitab Undang-Undang Hukum Acara Pidana dan pendaftarannya dilaksanakan pada saat terpidana diterima di Lapas. Begitu juga 
pembebasannya dilaksanakan pada saat narapidana telah selesai menjalani masa pidananya, yang dimaksud dengan pembebasan dalam hal ini termasuk juga pelepasan atau pengeluaran narapidana dari Lapas.

Menurut Pasal 2 UU No. 12 Tahun 1995 tujuan diselenggarakannya sistem pemasyarakatan dalam rangka membentuk Warga Binaan Pemasyarakatan agar menjadi manusia seutuhnya, menyadari kesalahan memperbaiki diri, dan tidak mengulang tindak pidana, sehingga dapat diterima kembali oleh lingkungan masyarakat, dapat aktif berperan dalam pembangunan dan dapat hidup secara wajar sebagai warga yang baik dan bertanggungjawab. Dalam penjelasan Pasal 2 UU No. 12 Tahun 1995 yang dimaksud dengan agar menjadi manusia seutuhnya, merupakan upaya untuk memulihkan Narapidana dan Anak Didik Pemasyarakatan kepada fitrahnya dalam hubungan manusia dengan Tuhannya, manusia dengan pribadinya, manusia dengan sesamanya, dan manusia dengan lingkungannya.

Pasal 3 UU No. 12 Tahun 1995 menegaskan bahwa fungsi sistem pemasyarakatan menyiapkan Warga Binaan Pemasyarakatan agar dapat berintegrasi secara sehat dengan masyarakat, sehingga dapat berperan kembali sebagai anggota masyarakat yang bebas dan bertanggungjawab. Yang dimaksud dengan berintegrasi secara sehat, adalah pemulihan kesatuan hubungan Warga Binaan Pemasyarakatan dengan masyarakat. Berdasarkan ketentuan Pasal 6 UU No. 12 Tahun 1995, dinyatakan Pembinaan Warga Binaan Pemasyarakatan dilakukan di Lapas dan pembimbingan Warga Binaan Pemasyarakatan dilakukan oleh Balai Pemasyarakatan (BAPAS). Sedangkan pembinaan di Lapas dilakukan terhadap Narapidana dan Anak Didik Pemasyarakatan.

Pembinaan Warga Binaan Pemasyarakatan di Lapas dilaksanakan: secara intramural (di dalam Lapas) Pembinaan secara intramural yang dilakukan di Lembaga Pemasyarakatan disebut asimilasi, yaitu proses pembinaan Warga Binaan Pemasyarakatan yang telah memenuhi persyaratan tertentu dengan membaurkan mereka ke dalam kehidupan masyarakat; dan ekstramural (di luar Lapas) Pembinaan secara extramural juga dilakukan oleh BAPAS yang disebut integrasi, yaitu proses pembimbingan Warga Binaan Pemasyarakatan yang telah memenuhi persyaratan tertentu untuk hidup dan berada kembali di tengah-tengah masyarakat dengan bimbingan dan pengawasan BAPAS.

Pasal 6 ayat (3) UU No. 12 Tahun 1995 ditegaskan pembimbingan oleh BAPAS dilakukan terhadap Terpidana bersyarat dan Narapidana, Anak Pidana dan Anak Negara yang mendapat pembebasan bersyarat atau cuti menjelang bebas, dan Anak Negara yang berdasarkan putusan pengadilan, pembinaan diserahkan kepada orangtua asuh badan sosial, serta Anak Negara yang berdasarkan Keputusan Menteri atau pejabat di lingkungan Direktorat Jenderal Pemasyarakatan yang ditunjuk, bimbingannya diserahkan orangtua asuh atau badan sosial; dan Anak yang berdasarkan penetapan pengadilan, bimbingannya dikembalikan kepada orangtua atau walinya.

Pembimbingan oleh BAPAS terhadap Anak Negara yang berdasarkan putusan pengadilan, pembimbingan diserahkan kepada orangtua asuh atau badan sosial, karena pembimbingannya, masih merupakan tanggung jawab Pemerintah. Terhadap Anak Negara yang berdasarkan Keputusan Menteri atau pejabat di lingkungan Direktorat Jendral Pemasyarakatan yang ditunjuk, bimbingannya diserahkan kepada orangtua asuh atau badan sosial, pembimbingannya tetap dilakukan oleh BAPAS karena anak tersebut masih berstatus Anak Negara. Pembimbingannya oleh BAPAS terhadap Anak yang berdasarkan penetapan pengadilan, bimbingannya dikembalikan kepada orangtua atau walinya dilakukan sepanjang ada permintaan dari orangtua atau walinya kepada BAPAS.

Pemasyarakatan yang merupakan bagian akhir dari sistem pemindanaan dalam tata peradilan adalah bagian integral dari tata peradilan terpadu (integrated criminal juctice sistem). Dengan demikian, pemasyarakatan baik ditinjau dari sistem, kelembagaan, cara pembinaan, dan petugas pemasyarakatan, merupakan bagian yang tak terpisahkan dari satu rangkaian proses penegakan hukum.

\section{Kendala yang Dihadapi Petugas Lapas untuk Membentuk Kepatuhan Hukum Narapidana sebagai Upaya Pencegahan Tindak Pidana di Lapas}

Dengan dikembangkannya pendakatan baru ini, maka para Kepala Lapas (Kalapas) dan Kepala Rutan (Karutan), Kepala Cabang Rutan (Kacabrutan) 
sebagai pengambil kebijakan untuk meningkatkan kemampuan baik di bidang manajemen intern organisasi sendiri maupun dalam melakukan terobosan yang mampu meningkatkan keterampilan bagi narapidana untuk mampu hidup mandiri di dalam masyarakat dan berpartisipasi dalam pembangunan nasional pada keseluruhannya. Penelitian dilakukan di 7 Lapas dengan memperoleh data sebagai berikut:

Pembinaan narapidana berpatokan pada Sepuluh Prinsip Pemasyarakatan, yaitu: Ayomi dan berikan bekal hidup agar mereka dapat menjalankan peranannya sebagai warga masyarakat yang baik dan berguna, dan Penjatuhan pidana bukan tindakan balas dendam negara. Memberikan bimbingan bukan penyiksaan supaya mereka bertobat. Negara tidak berhak membuat mereka menjadi lebih buruk atau jahat daripada sebelum dijatuhi pidana. Selama kehilangan kemerdekaan bergerak, para narapidana dan anak didik harus dikenalkan dengan dan tidak boleh diasingkan dari masyarakat, dan Pekerjaan yang diberikan kepada narapidana dan anak didik tidak boleh diberikan pekerjaan untuk memenuhi kebutuhan dinas atau kepentingan negara sewaktuwaktu saja. Pekerjaan yang diberikan harus satu dengan pekerjaan di masyarakat dan yang menunjang usaha peningkatan produksi, Bimbingan dan didikan yang diberikan kepada narapidana dan anak didik harus berdasarkan Pancasila, Narapidana dan anak didik sebagai orang-orang yang tersesat adalah manusia, dan mereka harus diperlakukan sebagai manusia. Narapidana dan anak didik hanya dijatuhi pidana hilang kemerdekaan sebagai salah satu derita yang dialaminya. Disediakan dan dipupuk saranasarana yang dapat mendukung fungsi rehabilitatif, korektif, dan edukatif dalam Sistem Pemasyarakatan. ${ }^{12}$

Pembinaan narapidana harus banyak menyediakan alternatif metode pembinaan yang dapat dijadikan pilihan untuk masing-masing latar belakang, dan karakter narapidana yang berbedabeda. Pembina tidak dapat menyamaratakan metode pembinaan karena narapidana pada umumnya memiliki latar belakang dan karakter yang heterogen. Demikian juga dengan situasi dan kondisi lingkungan Lapas. Pembinaan yang efektif di samping harus memperhatikan situasi dan kondisi tempat pembinaan dilaksanakan. Situasi dan kondisi yang kondusif akan menunjang efektifitas pembinaan. Sebaliknya situasi

12 Pasal 1 angka 1 PP No. 31 Tahun 1999 tentang Pembinaan dan Pembimbingan Warga Binaan Pemasyarakatan. dan kondisi yang tidak kondusif akan menghambat efektifitas pembinaan. Pembina yang baik tidak saja dituntut untuk menguasai materi dan metode yang dipakai tetapi harus juga mampu menciptakan situasi dan kondisi yang sesuai sehingga peserta didik konsentrasi menyimak materi yang disampaikan.

Kendala-kendala yang dihadapi petugas dalam pembinaan narapidana sebagai berikut:

Pertama, Faktor Kultur (Budaya). Pembinaan narapidana nyatanya dapat dikatakan kurang berhasil karena kultur yang ada kurang mendukung tercapainya tujuan pemasyarakatan. Keberhasilan pencapaian sasaran sistem pemasyarakatan yang ditentukan oleh kultur (budaya) dilihat dari kepercayaan, nilai-nilai, tingkah laku yang diciptakan dan dikembangkan oleh Lapas sebagai dasar menentukan tujuan, konsesus, keunggulan kinerja, inovasi, kesatuan dan integrasi yang dijadikan norma atau pedoman bagi permasalahan Lapas, di Lapas adanya kultur yang positif yaitu komunikasi yang harmonis antara petugas dan narapidana dalam melakukan kerjasama pada kegiatan kerohanian, sehingga dapat meningkatkan kinerja petugas Lapas dan tercapai tujuan pembinaan seperti yang diharapkan.

Kedua, Faktor Over Kapasitas. Jumlah narapidana di Lapas Kelas II B Lamongan, Lapas Kelas II B Tuban, Lapas Kelas II A Sidoarjo, Lapas Kelas II B Mojokerto, Lapas Kelas II B Jombang, Lapas Kelas II A Pamekasan, dan Rutan Kelas II B Sampang berdasarkan data yang ada semua menunjukkan over kapasitas untuk tiap-tiap Lapas, sehingga masih jauh dari yang diharapkan dan sangat rawan timbulnya kejahatan di dalam Lapas. Over kapasitas merupakan kendala yang paling besar untuk bisa tercapainya pembinaan narapidana sesuai tujuannya karena akan berhadapan dengan sarana dan prasarana yang ada di Lapas, juga jumlah petugas pembina yang melaksanakan programnya.

Ketiga, Faktor Petugas Lapas. Petugas Lapas sebagai abdi negara mempunyai tugas memberikan pelayanan, pembinaan, dan bimbingan terhadap narapidana. Dalam melaksanakan tugasnya mengalami kendala dari jumlah petugas yang tidak seimbang dengan jumlah narapidana, apalagi ada yang mendapatkan tugas bergiliran (pagi, siang, dan malam). Selain itu kendalanya pada unsur kemampuan petugas Lapas dalam melakukan pembinaan. Di dalam melakukan pembinaan yang dibutuhkan kemampuan dalam bidang sosial atau 
kemasyarakatan dan psikologi atau kejiwaan. Karena narapidana perlu pendampingan untuk bisa menyadari kesalahannya dan mau kembali ke masyarakat dengan perbaikan perilaku. Kenyatannya seringkali narapidana selalu merasa tidak bersalah dan hanya menjalani takdirnya saja. Kondisi ini merupakan tugas petugas Lapas untuk bisa memberi pemahaman terhadap narapidana, tetapi dengan jumlah terbatas maka tidak bisa melaksanakan tugasnya dengan baik, dan tentunya hasilnya juga kurang baik. Akhirnya narapidana tidak bisa kembali ke masyarakat secara sempurna setelah selesai menjalani pemidanannya.

Keempat, Faktor Masyarakat atau Keluarga Narapidana. Keluarga merupakan faktor pertama kembalinya narapidana setelah menjalani pemidanaan. Seringkali narapidana merupakan aib atau mencemarkan nama bagi keluarga karena dianggap merusak atau mencemarkan keluarga karena perbuatan pidana yang telah dilakukan. Kondisi ini merupakan faktor gagalnya pembinaan karena narapidana merasa terasing dalam keluarganya, sulit bergaul seperti semula. Selain itu label yang ada di masyarakat terhadap narapidana sampai sekarang belum pernah hilang, sehingga membatasi ruang gerak narapidana dalam bergaul maupun mencari pekerjaan. Kondisi ini sudah terbayang sejak narapidana dalam menerima pembinaan dalam Lapas karena menganggap tidak ada gunanya, tidak penting, tidak sesuai dengan minatnya.

Kelima, Faktor Anggaran untuk Pembinaan Narapidana. Anggaran yang terbatas sebagai kendala dalam pembinaan, sehingga tidak bisa memenuhi kebutuhan narapidana sesuai dengan amanat UU No. 12 Tahun 1995 tentang Pemasyarakatan sehingga mereka tidak serius dalam. Keterbatasan anggaran tersebut berdampak pembinaan hanya pengisi waktu saja, tidak bisa melakukan inovasi pembinaan sesuai perkembangan ilmu dan teknologi dan kebutuhan minat narapidana.

\section{Model Interaksi Humanis Petugas Lapas dengan Narapidana Sebagai Paradigma Baru dalam Upaya Pencegahan Terjadinya Tindak Pidana di Lapas}

Petugas pemasyarakatan sebagai abdi negara dan abdi masyarakat wajib menghayati serta mengamalkan tugas-tugas pembinaan pemasyarakatan dengan penuh tanggung jawab. Pembinaan terhadap narapidana pada dasarnya memberikan pelayanan, pembinaan dan bimbingan yang dilakukan oleh petugas pemasyarakatan agar tujuan pembinaan tercapai.

Pemasyarakatan adalah suatu proses pembinaan narapidana yang sering pula disebut therapeutics process, maka jelas bahwa membina narapidana itu sama artinya dengan menyembuhkan seseorang yang sementara tersesat hidupnya karena adanya kelemahan-kelemahan yang dimilikinya. ${ }^{13}$ Untuk mengatasi kelemahan-kelemahan itu, maka dapat ditempuh beberapa pendekatan antara lain dengan membuat Kode Perilaku dalam Lapas bagi narapidana yang dituangkan di dalam Catur Dharma Narapidana.

Catur Dharma Narapidana adalah ikrar sebagai berikut: 1. Kami narapidana, berjanji menjadi manusia susila yang berpancasila dan menjadi manusia pembangunan yang aktif dan produktif; 2 . Kami Narapidana, menyadari dan menyesali sepenuhnya perbuatan pelanggaran hukum yang pernah kami lakukan dan berjanji tidak akan mengulangi lagi perbuatan tersebut; 3. Kami narapidana, berjanji untuk memelihara tata karma dan tata tertib melakukan perbuatan yang utama dan menjadi teladan dalam Lapas; 4. Kami narapidana, dengan tulus ikhlas bersedia menerima bimbingan, dorongan dan teguran serta patuh, taat dan hormat kepada petugas dan pembimbing pemasyarakatan. ${ }^{14}$

Secara umum pembinaan narapidana bertujuan agar mereka dapat menjadi manusia seutuhnya sebagaimana yang telah menjadi arah pembangunan nasional melalui jalur pendekatan: 1. Memantapkan iman (ketahanan mental) mereka; 2. Membina mereka agar mampu berintegrasi secara wajar di dalam kehidupan kelompok selama dalam Lapas dan kehidupan yang lebih luas (masyarakat) setelah menjalani pidananya.

Secara khusus pembinaan narapidana ditujukan agar selama masa pembinaan dan sesudah selesai menjalankan masa depannya: 1. Berhasil memantapkan kembali harga diri dan kepercayaan dirinya serta bersikap optimis akan masa depannya; 2. Berhasil memperoleh pengetahuan, minimal ketrampilan untuk bekal mampu hidup mandiri dan berpartisipasi dalam kegiatan pembangunan nasional; 3. Berhasil menjadi manusia yang patuh hukum yang tercermin pada sikap dan perilakunya yang tertib

13 Departemen Kehakiman RI, Himpunan Peraturan Perundang-undangan tentang Pemasyarakatan, Jilid 6 , Jakarta, 2000, h. 56.

${ }^{14}$ Ibid., h. 56. 
disiplin serta mampu menggalang kesetiakawanan sosial; 4. Berhasil memiliki jiwa dan semangat terhadap bangsa dan negara.

Khusus bagi para tahanan, kegiatan yang diberikan kepada mereka bukan hanya semat-mata dimaksudkan sebagai kegiatan pengisi waktu agar terhindar dari pemikiran-pemikiran yang negatif (seperti berusaha melarikan diri), tetapi harus lebih dititikberatkan pada penciptaan kondisi yang dapat melancarkan jalannya proses pemeriksaan perkaranya di pengadilan. Bagi bekas narapidana, pembinaan yang diberikan lebih didasarkan pada tanggung jawab moral dari pihak masyarakat karena sebenarnya mereka telah bebas.

Meskipun demikian, dalam rangka mereka memudahkan untuk mengintegrasikan dan menyesuaikan diri dengan kehidupan masyarakat, maka tetap perlu dilakukan hubungan dengan mereka yang bertujuan agar: Mereka dapat merasakan bahwa sebagai pribadi dan warga negara Indonesia mampu berbuat sesuatu untuk kepentingan bangsa dan negara seperti pribadi dan warga negara Indonesia yang lainnya, dan Mereka dapat menjadi unsur pemasyarakatan yang mampu menciptakan opini dan citra pemasyarakatan yang baik.

Dalam hubungan inilah pemasyarakatan penting artinya bukan saja karena merupakan sarana untuk membina para narapidana dan tahanan sebagai manusia pembangunan guna meningkatkan kemampuan hidup mandiri di tengah-tengah masyarakat kelak, tetapi dengan diberikannya pendidikan kesadaran bernegara termasuk untuk mengetahui hak-hak dan kewajiban-kewajiban, maka pemasyarakatan merupakan juga sebagai sarana pendidikan dan sarana pembangunan. Dengan dasar pemikiran tersebut, maka konsep pemasyarakatan pada hakikatnya adalah juga pemasyarakatan manusia Pancasila yang turut berperan di dalam pembangunan, sebagai salah satu lembaga pendidikan dan pembangunan.

Dengan dikembangkannya fungsi pemasyarakatan yang terbuka dan produktif yang bertujuan turut menggiatkan kegiatan-kegiatan sosial ekonomi untuk kepentingan mereka sendiri dan untuk kepentingan pembangunan, maka langkah-langkah pembinaan keamanan dan ketertiban dalam setiap lembaga pamasyarakatan dan rumah tahanan Cabang rutan (Cabrutan) pun dilaksanakan sesuai dengan tingkat keadaan (situasi) mulai hidup dengan maximum security, medium security dan minimum security.
Dengan ciri-ciri tersebut, maka Lapas bukan saja harus merubah dalam pola pembinaan yang dilakukan tetapi sekaligus juga sudah merubah orientasinya dari lembaga konsumtif menjadi lembaga produktif. Untuk mendukung kebutuhan orientasi baru ini, maka sudah tepatlah kalau semua jajaran pemasyarakatan mampu menangkap perubahan orientasi tersebut dan menjabarkannya dalam kegiatan pembinaan.

Pemasyarakatan saat ini jelas memiliki potensi sumber daya manusia berupa tenaga kerja (narapidana). Disamping itu, oleh karena Lapas dan Rutan/ Cabrutan atau di bawah pertanggungjawabannya terdapat kekayaan seperti lahan yang belum diolah atas dasar kerjasama dengan pihak pengusaha (negara maupun swasta) yang tenaga-tenaga pekerjanya keseluruhannya atau sebagainya terdiri dari para narapidana.

Berdasarkan pemikiran pembinaan di atas, maka pelaksanaan program pembinaan narapidana adalah merupakan kegiatan untuk meningkatkan kualitas ketaqwaan kepada Tuhan Yang Maha Esa, intelektual, sikap dan perilaku, professional, kesehatan jasmani dan rohani narapidana serta anak didik pemasyarakatan yang telah diprogramkan. ${ }^{15}$ Dengan ruang lingkup pembinaan yaitu: Pembinaan Kepribadian, dan Pembinaan kemandirian.

Di samping program pembinaan yang telah dijelaskan di atas, maka dalam pelaksanaan, program pembinaan tersebut terdapat 3 (tiga) elemen yang menentukan keberhasilan program pembinaan yaitu petugas, masyarakat dan narapidana itu sendiri. Dengan adanya program pembinaan tersebut di Lapas maka secara tidak langsung, ketiga elemen tersebut akan berperan aktif dalam pelaksanaan program pembinaan di Lapas secara garis besar terbagi dalam:

Pertama, Pembinaan Promotial. Merupakan pembinaan yang bertujuan meningkatkan kemampuan pribadi dan mengefektifkan potensi pribadi narapidana melalui pembinaan mental spiritual, pembinaan jasmani, keterampilan serta pembinaan meningkatkan pendidikan umum. Berkaitan dengan Lapas terbuka yang akrab dengan bidang pertanian dan peternakan, maka biasanya terdapat program pendidikan keterampilan di bidang pertanian dan peternakan.

15 Pasal 1 Angka 1 PP RI No. 31 Tahun 1999 tentang Pembinaan dan Pembimbingan Warga Pemasyarakatan (Himpunan Peraturan Perundang-undangan tentang Pemasyarakatan), h. 554. 
Kedua, Pembinaan Sosial. Pembinaan yang bertujuan untuk memperbaiki hubungan antara narapidana dengan masyarakat, dengan memberikan kesempatan kepada narapidana untuk mengatasi kembali aspek-aspek pribadinya yang mendasari hubungan dengan masyarakat. Program ini dapat berupa pemberian keleluasaan yang lebih besar kepada narapidana untuk berintegrasi dengan masyarakat dan lingkungan Lapas seperti kerja bakti, peringatan hari besar, ibadah bersama dan lain-lain.

Akhirnya pemberian pembebasan bersyarat dan cuti menjelang bebas dapat diberikan kepada narapidana di Lapas. Sebagai langkah akhir sebelum di benar-benar kembali ke tengah-tengah masyarakat. Dalam pelaksanaannya, program pembinaan narapidana di Lapas dilaksanakan melalui beberapa tahap. ${ }^{16}$

Pembinaan menurut sistem pemasyarakatan berdasarkan pada falsafah Pancasila dan UndangUndang Dasar 1945. Dalam Pembukaan UndangUndang Dasar 1945 ditegaskan bahwa pembentukan pemerintah Negara Republik Indonesia adalah untuk mewujudkan kesejahteraan umum, mencerdaskan kehidupan bangsa dan ikut melaksanakan ketertiban dunia berdasarkan kemerdekaan perdamaian abadi dan keadilan sosial. Dari penegasan Undang-Undang Dasar 1945 jelaslah bahwa narapidana walaupun telah dijatuhi pidana hilang kemerdekaan oleh suatu putusan hakim ia tetap sebagai warga Negara dan sebagai warga Negara ia masih mempunyai asasi seperti orang lain.

Narapidana sebagai subjek pembinaan yang dilakukan oleh Lapas, karena ia diharapkan dapat menjadi contoh tauladan yang baik di antara sesama narapidana. Narapidana yang akan dibina oleh Lapas itu terdiri dari beberapa golongan, penggolongan ini dimaksudkan untuk mempermudah program pembinaan, karena pembinaan adalah rangkaian suatu program yang memerlukan waktu yang cukup lama.

Adapun penggolongan narapidana tersebut adalah sebagai berikut: Golongan B I (Hukuman penjara lebih dari satu tahun); Golongan B IIa (Hukuman penjara lebih dari tiga bulan sampai dengan satu tahun); Golongan B IIb (Hukuman penjara lebih dari satu hari sampai dengan tiga bulan); Golongan B III

16 Baharudin Soerjobroto, "Pelaksanaan Sistem Pemasyarakatan", Majalah Pembinaan Hukum, 1972, h. 78.
(Hukuman kurungan); Golongan B IIIs (Hukuman kurungan pengganti denda). ${ }^{17}$

Dari penggolongan di atas yang menjadi sasaran utama pembinaan adalah narapidana golongan B I, narapidana dari golongan lainnya tidak dapat dijadikan sasaran pembinaan, karena hukuman yang singkat sehingga tidak dapat diterapkan dalam tahap pembinaan.

Pembinaan sebagai salah satu kewenangan Lapas mempunyai beberapa tujuan yang hendak dicapai dalam pembinaan yaitu: Supaya narapidana tidak melanggar hukum lagi; Supaya narapidana aktif, produktif dan berguna dalam masyarakat; Supaya narapidana bahagia hidup di dunia dan di akhirat. ${ }^{18}$

Menurut Baharudin Soerjobroto, pembinaan narapidana bertujuan untuk memulihkan kesatuan hubungan hidup kehidupan dan penghidupan yang terjadi antara individu pelanggar hukum dengan pribadinya, antara pelanggar hukum dengan masyarakatnya, alam lingkungannya dan semua dalam hubungannya dengan Tuhan Yang Maha Esa. ${ }^{19}$

Keberhasilan proses pembinaan terhadap narapidana harus ada dukungan dari sumber daya manusia agar dapat bekerja dengan hasil yang optimal, khususnya dilihat dari sisi kepegawaian atau petugas, diantaranya: Pola pengadaan pegawai/pola rekruitmen petugas Lapas; Penempatan pegawai/petugas sesuai dengan keahlian; Sarana dan prasarana para petugas untuk menunjang kegiatan; Kesejahteraan petugas; Disiplin kepegawaian; Komunikasi atasan dan bawahan.

Hal-hal tersebut dapat meningkatkan produktifitas seorang petugas atau pegawai agar dapat melakukan pekerjaan dengan optimal dan tentu yang sangat diharapkan memiliki tingkat profesionalitas yang tinggi sehingga akan dapat menciptakan kinerja yang baik.

Pembahasan selanjutnya mengenai pola rekruitmen pegawai dalam kerangka reformasi birokrasi pada semua organisasi pemasyarakatan maka setidaknya ada ukuran yang jelas mengenai perlunya analisis kebutuhan dalam menyusun formasi, sehingga tidak terjadi lagi dimana kondisi

\footnotetext{
${ }^{17}$ Andi Hamzah, Sistem Pidana dan Pemidanaan Indonesia dari Retribusi ke Reformasi, Pradnya Paramita, Jakarta, 1985,

${ }^{18}$ Soemadipraja dan Romli Atmasasmita, Ibid., h. 15.

${ }^{19}$ Baharudin Soerjobroto, Ibid., h. 78.
} h. 25 . 
yang dibutuhkan tidak kunjung dipenuhi sesuai dengan kebutuhan.

Pola Rekruitmen pegawai Kementrian Hukum dan HAM tunduk pada peraturan pemerintah, akan tetapi berdasarkan pengalaman selama ini sekretaris Jenderal Kementrian Hukum dan HAM kurang memperhatikan karakteristik khusus yang harus dipenuhi dalam merekrut pegawai untuk memenuhi kebutuhan bagi pegawai pemasyarakatan berdasarkan hasil wawancara dengan Kakanwil Kementerian Hukum dan HAM Jawa Timur. Karakteristik khusus tersebut berkenaan dengan fungsi yang diemban oleh petugas pemasyarakatan disetiap unit-unit pelaksana teknis misalnya Rutan mengemban fungsi pelayanan, Bapas mengemban fungsi keterampilan kerja. Untuk mengembang fungsi tersebut dibutuhkan sumber daya manusia yang mempunyai keahlian misalnya Lapas membutuhkan Dokter, Psikiater, Psikolog dan tenaga fungsional lain seperti guru misalnya. Di sisi lain petugas pemasyarakatan mengetahui dan menguasai keseluruhan tugas dan fungsi tersebut dan unit pelaksana teknis secara utuh sehingga dapat menjadi insan penegak hukum yang professional.

Perlunya persyaratan khusus adalah sesuai dengan ketentuan Pasal 8 ayat (1) UU No. 12 Tahun 1995 tentang Pemasyarakatan dimana dikatakan bahwa petugas pemasyarakatan merupakan Pejabat Fungsional Penegak Hukum yang melaksanakan tugas dan fungsi di bidang pelayanan, pembinaan, pengamanan, dan pembimbingan serta perawatan. Dengan demikian Direktorat Jenderal Pemasyarakatan perlu membuat ketentuan-ketentuan yang dijadikan persyaratan khusus yang digunakan dalam rekrutmen petugas pemasyarakatan. Selain merekrut sarjana dari disiplin ilmu yang lain maka unsur utama dalam rekruitmen petugas pemasyarakatan adalah Sarjana Hukum mengingat tugas dan fungsinya sebagai Jabatan Fungsional penegak Hukum telah diatur dalam UU Pemasyarakatan. Yang tidak termasuk dalam criteria jabatan fungsional diarahkan untuk menduduki jabatan administrasi dan tata usaha. Pegawai/Petugas Lapas di Jawa Timur sebagai salah satu unsur yang ada dalam Lapas ikut menentukan dalam pelaksanaan program pembinaan terhadap narapidana dan keberhasilan penerapan pelaksanaan pola pembinaan pemasyarakatan yang digunakan untuk pembinaan narapidana.

Berdasarkan data sementara tingkat pendidikan di atas dapat ditarik kesimpulan bahwa masih sangat minimnya tingkat pendidikan dari para petugas, sementara kondisi kepegawaian ke depan dituntut dengan tantangan-tantangan yang begitu kompleks dan membutuhkan tenaga-tenaga terampil yang energik serta profesional, sehingga dengan hanya berbekal pendidikan SLTA saja akan sangat dirasakan kurang karena pengembangan wawasan berfikir secara ilmiah akan menjadi kurang tajam belum lagi dituntut untuk dapat memberikan analisa atas setiap permasalahan yang mungkin akan timbul.

Oleh karena itu peningkatan sumber daya manusia melalui jenjang pendidikan ini harus diprioritaskan oleh pihak pejabat struktural yang berwenang menanganinya agar peningkatan kinerja pegawai/ petugas Lapas dapat semakin meningkat, dan selain dengan hal tersebut juga peningkatan kesejahteraan pegawai pun akan semakin baik. Hal demikian ini yang akan ikut membantu dalam meningkatkan kinerja setiap individu pegawai.

Keterkaitan dengan proses pembinaan narapidana tentu akan sangat berpengaruh sekali pada tingkat pendidikan tersebut, sebagai contoh permasalahan kecil saja dimana Lapas adalah tempat berkumpulnya para narapidana, dimana narapidana adalah orangorang yang memiliki berbagai bentuk permasalahan dalam hidupnya, hal ini akan menjadikan pribadi tiap narapidana tersebut memiliki banyak kelemahan dan keputusasaan dalam diri narapidana tersebut, yang menjadikan permasalahan adalah bagaimana para petugas pemasyarakatan tersebut menyikapi permasalahan tersebut bila hanya berbekal pendidikan yang hanya pas-pasan saja, sementara dalam memecahkan setiap permasalahan yang begitu beraneka ragam memerlukan tingkat keahlian dan wawasan yang sangat dalam untuk dapat membantu narapidana yang sedang mengalami masalah tersebut. Inilah perlunya pendidikan lanjut khususnya ke perguruan tinggi kepada para pegawai agar dapat mngembangkan wawasan berfikirannya agar lebih tajam dan dapat menganalisis setiap permasalahan para narapidana dengan baik sehingga akan output yang merupakan solusi yang terbaik bagi narapidana.

Apabila ditinjau jabatan atau berdasarkan golongan kepangkatan data yang diperoleh dari Kasubbag Kepegawaian Lapas di Jawa Timur. Hal yang masih menujukkan angka wajar karena sema tinggi tingkat managerial dalam suatu organisasi maka makin sedikit populasinya, seperti dalam teori manajemen yang digambarkan dengan segitiga 
kerucut dimana semakin tinggi maka akan makin sedikit karena yang berada di puncak kerucut tersebut adalah level pejabat yang tinggi tentu jumlahnya akan semakin sedikit, apabila dihubungkan dengan tingkat pendidikan petugas yang didominasi SLTA, maka ini yang menjadi permasalahan karena akan terjadi kesenjangan sosial dalam hal golongan pegawai akan semakin jauh tertinggal dimana jarak antara pegawai dengan para pejabat struktural jauh sekali ini menghambat sistem dalam suatu organisasi hal ini terkait dengan masalah kaderisasi kepemimpinan pada Lapas di Jawa Timur tersebut.

Hal tersebut di atas sangat terhambat, dimana yang seharusnya pucuk pimpinan misalnya Sub Seksi saja bisa di ambil dari lingkungan intern Lapas di Jawa Timur tetapi karena formasi dari pegawai yang ada golongannya belum mencukupi atau ada tetapi mereka sudah usia lanjut dilihat dari segi prestasinya tanpak sudah tidak memungkinkan, yang ada akhirnya harus mengambil pejabat untuk menempati posisi tersebut dengan cara merekrut dari luar Lapas Kelas I Jawa Timur, hal-hal ini akan mudah menimbulkan konflik intern karena mungkin ada seseorang yang memiliki ambisi untuk mendudukki jabatan tersebut tetapi karena golongannya masih belum sampai sehingga yang bersangkutan akan menjadi kecewa, dan kekecewaan ini akan terus berlanjut yang pada akhirnya menurunkan prestasi kerja yang bersangkutan.

Keadaan tersebut tentu tidak diinginkan terjadi untuk itu perlu dilakukan kaderisasi dengan baik tentunya dengan cara pemberian kesempatan kepada para pegawai atau petugas untuk melanjutkan pendidikannya ke jenjang yang lebih tinggi dan bila sangat memungkinkan dari instansi Lapas dapat membantu dengan memberikan subsidi biaya pendidikan pegawainya tersebut agar mereka dapat lebih semangat lagi dan juga merasa diperhatikan selain itu akan dapat memberikan dampak yang positif dimana akan tumbuh perlahan-lahan loyalitas pada institusi tersebut, ini diharapkan agar mereka semua dapat kembali bekerja dengan baik dan dapat meraih prestasi yang terbaik sehingga menghasilkan kinerja yang baik pula.

Jumlah narapidana di Lapas di Jawa Timur di bagi-bagi menurut bagian-bagiannya dan semuanya melebihi kapasitas yang ada. Dengan jumlah tersebut masih jauh dari yang diharapkan dan sangat rawan menimbulkan hal-hal yang tidak diinginkan.
Bagaimana pembinaan akan berjalan dengan baik dan sesuai dengan sasaran dari peraturan yang mengatur tentang proses pembinaan sementara tenaga pembinaannya masih kurang meskipun pembinaan tetap berjalan tetapi dapat dipastikan hasil yang tidak optimal.

Kekurangan tenaga Pembina dalam arti tenaga pembina yang benar-benar memiliki kemampuan yang baik dalam mengakomodir kebutuhan-kebutuhan para narapidana dalam menyelesaikan berbagai masalah dan juga dalam memberikan pembinaan-pembinaan baik dalam bentuk keterampilan maupun kegiatan sosial lainnya membuat kondisi Lapas menjadi memperhatinkan hal ini dilihat dari kecukupan tenaga pembinaan.

Mengenai kecukupan tenaga pembinaan di Lapas di Jawa Timur kurang memadai. Hal ini dikarenakan jumlah petugas kurang sebanding dimana berdasarkan hasil wawancara dengan Kabid. Pembinaan yang menyatakan bahwa pada prinsipnya petugas/pegawai Lapas sebagaian pembina yang bertugas sebagai pengamanan dan pembinaan narapidana dengan melakukan koordinasi. Hal ini penulis menyimpulkan bahwa merupakan suatu cerminan pembinaan yang tidak berjalan dengan baik karena faktor pembina yang tidak memadai, dan hal ini memberikan gambaran kurangnya tenaga pembina bisa diakibatkan oleh terjadinya kelebihan penghuni atau sehingga program pembinaan tidak berjalan dengan baik. Pembahasan selanjutnya mengenai klualitas dari tenaga pembinaan, maka untuk menunjang kualitas tenaga pembinaan maka dilakukan Pendidikan dan Pelatihan Petugas Pemasyarakatan.

Pendidikan dan Pelatihan Petugas Pemasyarakatan diselenggarakan oleh Badan Pengembangan Sumber Daya Manusia Departemen Hukum dan HAM (selanjutnya disebut dengan BPSDM). Ketentuan organisasi dan tata kerja BPSDM diatur dalam Peraturan Menteri Hukum dan HAM R.I. Nomor: M.09-PR.07.10 Tahun 2007 tentang Organisasi dan Tata Kerja Departemen Hukum dan HAM R.I. Guna melaksanakan tugas dan fungsi pendidikan dan pelatihan dalam rangka pengembangan sumber daya manusia untuk seluruh unit kerja di Departemen Hukum dan Hukum maka organisasi BPSDM terbagi menjadi tiga pusat yakni: Pusat Pengembangan Kepemimpinan dan Manajemen, dan Pusat Pengembangan Teknis, serta Pusat Pengembangan Fungsional. 
Petugas Pemasyarakatan yang diusulkan untuk mengikuti pendidikan dan pelatihan di BPSDM maka secara umum mengikuti ketentuan Pendidikan dam Pelatihan berdasarkan agenda atau program yang disusun oleh BPSDM.

Kondisi empiris menujukkan bahwa ratarata petugas Pemasyarakatan tidak puas dengan penyelenggaraan diklat yang diselenggarakan oleh BPSDM. Salah satu faktor penyebab tidak efisiennya penyelenggaraan diklat disebabkan struktur organisasi BPSDM dilakukan dengan pendekatan sistem fungsi yang terbagi atas Pusat Kepemimpinan dan Manajemen, Pusat Pengembangan Teknis dan Pusat Pengembangan Fungsional dan HAM, keseluruhan Pusat ini mengadakan pelatihan untuk seluruh unit utama di Departemen Hukum dan HAM termasuk Direktorat Jenderal Pemasyarakatan. Dengan pendekatan fungsi ini kekhusussan pengembangan SDM bidang Pemasyarakatan kurang terlaksana dengan baik. Adanya sistem diklat terpusat ini menimbulkan efek negatif karena masih banyak petugas pemasyarakatan yang belum mengikuti diklat hingga memasuki tahap pensiunnya. Fakta ini perlu disikapi secara serius oleh Direktorat Jenderal Pemasyarakatan.

Jika diutamakan dengan pendekatan perbidang misalnya diharapkan pendidikan dan pelatihan untuk meningkatkan kualitas sumber daya manusia pegawai pemasyarakatan lebih terarah dan dapat menunjang kekhususan masing-masing bidang. Yang dimaksud dengan pendekatan per bidang adalah spesifikasi pelaksanaan diklat akan terbagi menjadi: Pertama, Diklat Prajabatan adalah Pendidikan dan Pelatihan yang wajib ditempuh oleh Calon Pegawai Negeri Sipil di lingkungan Departemen Hukum dan HAM sebagai persyaratan untuk dapat diangkat menjadi Pegawai Negeri Sipil. Kedua, Diklat Dalam Jabatan. Untuk mencapai kompentensi yang sesuai dengan jenis dan jenjang jabatan fungsional tertentu seperti Dokter, Psikolog, Psikiater, Arsiparis, Bendahara dan lain-lain yang mendukung pelaksanaan tugas dan fungsi Pemasyarakatan.

Kurang pemahaman terhadap mekanisme peraturan di bidang pembinaan adalah suatu indikasi bahwa kualitas tenaga pembina dirasakan kurang, kurangnya kualitas tenaga pembina sangat dipengaruhi oleh tingkat pendidikan maupun ketidakpahaman dan kebijakan-kebijakan yang sudah ada atau pun tidak memahami akan maksud dan tujuan dari kebijakan yang dikeluarkan pimpinan, sehingga mengakibatkan rendahnya kualitas sumber daya manusia yang sudah ada di lingkungan Lapas yang bersangkutan, sehingga hal ini dapat dikatakan bahwa kualitas tenaga pembinaan yang ada di Lapas masih sangat kurang, hal ini dikarenakan kompetensi yang dimiliki petugas masih sangat kurang.

Pada kondisi seperti ini manajemen seharusnya tanggap dan segera melakukan perbaikan-perbaikan agar kinerja petugas tidak semakin merosot kualitasnya, sehingga dapat diantisipasi gejala-gejala yang tidak diinginkan.Untuk mencapai perbaikan tersebut tentu memerlukan pengorbanan besar dari pejabat yang terkait, baik pengorbanan waktu, pengorbanan terhadap kepentingan pribadi dalam hal dedikasi dan loyalitas sangat dikedepankan. Sementara narapidana sangat membutuhkan tenaga pembina yang memiliki kualitas yang baik dengan begitu setiap narapidana akan memperoleh pembinaan yang positif dan berkelanjutan karena pembinaan kelak kemudian akan menjadi bekal yang sangat berharga bagi narapidana setelah mendapatkan kebebasan.

Rata-rata tingkat pendidikan formal pada Lapas di Jawa Timur dari hasil pengumpulan data menunjukan pada tingkat pendidikan SLTA menunjukan dominasi yang cukup besar. Secara psikologis dengan tingkat pendidikan yang rata-rata SLTA (SMU) maka wawasan berfikirnya masih belum berkembang dan daya analisis atas suatu permasalahannya. Apabila pendidikan dan latihan oleh pihak Lapas jarang diberikan kepada para pegawainya sehingga semakin tertinggal saja wawasan dan ilmu pengetahuan dengan tingkat pendidikan yang hanya rata-rata SLTA dan pemahaman dalam bidang pekerjaan sangat kurang menguasai dan akhirnya timbul adalah seorang pegawai yang memiliki tipe pegawai yang status dalam arti motivasi untuk mengejar prestasi yang lebih baik dan tidak ada keinginan untuk meraih karier dengan cepat dan cara yang sehat.

Program pendidikan dan latihan kepada pegawai merupakan program pengembangan dalam pekerjaan sehingga diikutsertakan dalam program pendidikan dan latihan maka seseorang seharusnya menjadi lebih terampil dan lebih berkembang. Dari hasil wawancara dengan para petugas pembinaan yang menjadi informen tentang pelaksanaan program Pendidikan dan latihan yang pada umumnya semua respoden menyatakan bahwa sebagian besar telah mengikuti 
pendidikan dan latihan (diklat), terutama pada petugas pengamanan mengikuti pendidikan dan latihan teknis pemasyarakatan (diklat teknis). ${ }^{20}$ Sehingga hal ini dapat dikatakan bahwa tenaga pembina Lapas di Jawa Timur belum sepenuhnya mengikuti pendidikan dan latihan teknis pemasyarakatan yang bersifat teknis. Hal ini menunjukan program diklat tidak berjalan lancar secara otomatis para pegawainya yang tidak mengikuti program tersebut terus bekerja tanpa keahlian sehingga tidak berkembang dan tidak mempunyai keahlian yang baik terhadap beban pekerjaan dibebankannya tersebut. Oleh karena itu kecekatan pejabat khususnya kepala Lapas untuk manangakap sinyal seperti ini diharapkan dapat segera melakukan tindakan perubahan-perubahan ke arah perbaikan kinerja khususnya dengan member kesempatan kepada para bawahannya untuk mengikuti pelatihan-pelatihan yang sesuai dengan bidang pekerjaan masing-masing. Pembahasan selanjutnya mengenai pendanaan bahwa dukungan dana pembinaan bagi narapidana di Lapas di Jawa Timur masih dalam tahap baik.

Hal tersebut menunjukan bahwa dukungan dan pembinaan pada Lapas tersebut sangat minim sekali, sehingga sulit bagi Lapas untuk dapat mengimplementasikan Surat Keputusan Menteri Kehakiman tersebut (Keputusan Menteri Kehakiman RI No: M.02-PK.04.10 Tahun 1990 tentang Pola Pembinaan Narapidana) baik karena tidak adanya dukungan dari sisi pembiayaan, pada kenyataannya di lapangan semua kegiatan memerlukan biaya dan dengan dana yang cukup maka semua program kegiatan dapat berjalan dengan lancar. Sulit memang untuk dapat melaksanakan seperti yang disebutkan pada Surat tersebut yang menyatakan bahwa, sekalipun dirasakan kurang mencukupi untuk kebutuhan seluruh program pembinaan, namun hendaklah diusahakan memanfaatkan anggaran yang tersedia secara berhasil guna dan berdaya guna, pada kenyataan dukungan dana sangat dibutuhkan sekali, kepada para pelaksana kegiatan juga tanpa adanya dana pendukung mereka tidak akan dapat bersemangat dalam melaksanakan program tersebut sehingga dukungan dana memberikan dampak yang sangat signifikan sekali untuk dinyatakan suatu program dapat berjalan dengan baik atau tidak. Tetapi yang sangat disayangkan adalah sumber dana

\footnotetext{
${ }^{20}$ Wawancara dengan Petugas Bagian Pembinaan Keamanan di Lapas Kelas I Jawa Timur, 2011.
}

pendukungnya sudah ada tetapi dalam pemanfaatan dana tersebut tidak sesuai dengan program yang sedang dijalankan ataupun bila dijalankan untuk program tersebut tetapi dana tersebut tidak digunakan dengan maksimal dalam arti penggunaannya tidak terkontrol dengan baik.

Mengenai dukungan sarana kegiatan yang menunjang lancarnya proses pembinaan di Lapas di Jawa Timur berdasarkan hasil pengamatan secara langsung dan hasil wawancara dengan petugas Lapas yang menjadi informan dalam penelitian ini, tingkat dukungan masih kurang memenuhi kreteria kebutuhan untuk pembinaan narapidana. Sehingga dapat disimpulkan bahwa penyediaan sarana kegiatan pembinaan bagi para narapidana pun sangat kurang sekali. Kondisi ini membuat semakin sulit untuk dapat mengimplementasikan Surat Keputusan Menteri Kehakiman tersebut sebagaimana diharapkan oleh para pejabat yang berwenang dan narapidana itu sendiri. Karena masalah pelaksana pembinaan narapidana yang diasumsikan turut menyebabkan belum optimalnya pembinaan terhadap narapidana yaitu masih terbatasnya sarana keterampilan kerja bagi narapidana sehingga masih banyak narapidana yang tidak mempunyai kegiatan, yang mengakibatkan narapidana hanya menunggu habis masa pidananya tanpa mendapat keahlian yang akan bermanfaat bagi narapidana itu sendiri.

Dengan tidak adanya sarana yang mendukung ditambah dana pelaksanaan program sangat minimal sekali maka menjadi masalah yang sangat serius dalam pelaksanaan pembinaan bagi para narapidana yang ada di Lapas di Jawa Timur tidak dapat berjalan seperti yang diharapkan. Sedangkan efek atau akibat berikutnya adalah dengan semakin kurang terbinanya para narapidana maka akan menimbulkan kekosongan kegiatan, dengan tidak adanya kegiatan maka para narapidana akan lebih sensitif dengan membuat kegiatan sendiri yang cenderung bersifat negatif yaitu kegiatan yang mudah memicu keributan, perkelahian sehingga dapat mengganggu keamanan dan ketertiban Lapas itu sendiri, hal ini terjadi karena kurangnya perhatian dan pengarahan dari para pembina pemasyarakatan terhadap narapidana.

Dana pendukung kegiatan masih kurang baik, kemudian juga sarana kegiatan yang tidak menunjang kegiatan maka para pembina sudah pasti tidak memiliki semangat dalam melaksanakan kegiatan yang telah dicanangkan dan bagaimana pula dengan 
dukungan instansi lain di luar Lapas karena sumber pendanaannya saja sangat minim. Mayoritas informan menyatakan bahwa dukungan dari instansi lain di luar sangat kurang hanya beberapa saja. Seperti halnya yang ada saat ini salah satunya adalah program kerja pembinaan narapidana, khususnya sasaran pembinaan kemandirian atau produktif ada bantuan kerjasama dengan Deperindag dan penanggungjawabnya seksi bimbingan kerja, adapun kegiatannya antara lain pembuatan ornament, pot kembang, paving blok, perkayuan, percetakan, serta jahitan.

Dengan semua kriteria pendukung tidak terpenuhi maka dukungan pihak instansi lain di luar Lapas, akan sulit melakukan kerjasama di dalam hal pembinaan karena apa pun yang dilakukan yaitu misalnya kehadirannya untuk melakukan penyuluhan, bimbingan-bimbingan maupun memberikan keterampilan bila sarana dan dana tidak ada maka akan menjadi kurang memberikan hasil yang maksimal atas kedatangan para petugas dari instansi di luar Lapas tersebut. Hal ini merupakan permasalahan yang membutuhkan perhatian yang sangat serius agar pembinaan kepada narapidana dapat berjalan dengan baik, karena dengan tidak berjalannya program pembinaan aka nada dampak yang muncul pada narapidana ini yang harus diantisipasi dan perlu dicermati dengan baik, jangan sampai terjadi narapidana menjadi warga yang tidak terbina karena jika ini terjadi maka fungsi dan tujuan Lapas menjadi sudah tidak efektif lagi.

\section{PENUTUP}

\section{Kesimpulan}

Hasil analisis terhadap Undang-Undang No. 12 Tahun 1995 tentang Pemasyarakatan, dan penelitian di beberapa Lapas di Jawa Timur dapat disimpulkan sebagai berikut:

Pertama, Pengaturan sistem pembinaan narapidana didasarkan Undang-Undang No. 12 Tahun 1995 dan PP No. 31 Tahun 1999 bahwa pembinaan warga binaan pemasyarakatan dilakukan di Lapas, dan pembimbingan warga binaan pemasyarakatan dilakukan oleh BAPAS (Balai Pemasyarakatan). Pembinaan dilakukan dengan dua cara yaitu: a. Secara intramural (di dalam Lapas) yang disebut asimilasi yaitu proses pembinaan warga binaan pemasyarakatan yang telah memenuhi persyaratan tertentu dengan membaurkan mereka ke dalam kehidupan masyarakat; b. Secara ekstramural (di luar Lapas) yang disebut integrasi yaitu proses pembimbingan warga binaan pemasyarakatan yang telah memenuhi persyaratan tertentu untuk hidup dan berada kembali di tengah-tengah masyarakat dengan bimbingan dan pengawasan Bapas.

Kedua, Kendala yang dihadapi petugas Lapas untuk membentuk kepatuhan hukum narapidana dalam beberapa Lapas di Jawa Timur antara lain: Faktor kultur (budaya), Faktor over kapasitas, Faktor petugas Lapas, Faktor masyarakat/keluarga narapidana, dan Faktor anggaran untuk pembinaan narapidana.

Ketiga, Model interaksi humanis petugas Lapas dengan narapidana sebagai paradigma baru dalam mencegah terjadinya tindak pidana yaitu model interaksi di dalam Lapas berdasarkan 10 Prinsip Pemasyarakatan, namun di dalam pelaksanannya menghadapi beberapa kendala sehingga sulit mencapai tujuan pembinaan secara maksimal. Oleh karena itu perlu perubahan paradigma baru dalam melakukan pembinaan yang menempatkan narapidana sebagai subyek bukan obyek pembinaan. Sehingga pelaksanaan pembinaan juga didiskusikan dengan narapidana agar ikut bertanggungjawab terhadap setiap kegiatan. Selain itu perlu kebijakan Kalapas untuk merubah orientasi pemasyarakatan dari lembaga konsumtif menjadi lembaga produktif dengan memanfaatkan jumlah narapidana sebagai tenaga kerja, kemampuan narapidana sebagai pembimbing kegiatan dan memanfaatkan lahan yang belum diolah atas dasar kerjasama dengan pihak pengusaha (negara maupun swasta) dengan tenaga kerja dari narapidana.

\section{Rekomendasi}

Berdasarkan hasil penelitian, maka peneliti mencoba memberi saran untuk keberhasilan pembinaan narapidana di Lapas sebagai berikut:

Pertama, Berkaitan dengan pelaksanaan UndangUndang No. 12 Tahun 1995 tentang Pemasyarakatan, kepada Pemerintah RI supaya segera membuat peraturan pelaksanaan dari undang-undang tersebut karena sampai sekarang masih banyak beberapa pasal belum ada peraturan pelaksanannya.

Kedua, Berkaitan dengan kendala-kendala pembinaan narapidana, kepada Kementerian Hukum dan HAM RI supaya memperhatikan spesialisasi petugas pembina narapidana diawali rekruitmen pegawai, pelatihan dan penempatannya, agar bisa 
mengatasi kendala kultur, struktur dan substansi di Lapas. Untuk bisa tercapai tujuan pembinaan narapidana untuk menjadi warga negara yang utuh, bisa melaksanakan hak dan kewajibannya.

Ketiga, Berkaitan dengan model interaksi humanis petugas pembina dengan narapidana kepada Kepala Lapas supaya bisa merubah orientasi pemasyarakatan dari lembaga konsumtif menjadi lembaga produktif dalam kegiatan pembinaan narapidana, karena pemasyarakatan memiliki potensi sumber daya manusia berupa tenaga kerja narapidana. Oleh karena Kalapas sebagai pengambil kebijakan untuk meningkatkan kemampuan petugas Lapas dalam memperlakukan narapidana tidak lagi sebagai obyek tetapi sebagai subyek yang ikut berperan dalam semua kegiatan yang ada dengan bermacam keterbatasannya. Perlakuan ini untuk menumbuhkan tanggung jawab narapidana tanpa memperdulikan sikap atau perilaku masyarakat.

\section{DAFTAR PUSTAKA}

\section{Peraturan Perundang-undangan:}

Undang-Undang Nomor 12 Tahun 1995 tentang Pemasyarakatan.

Peraturan Pemerintah Nomor 31 Tahun 1999 tentang Pembinaan dan Pembimbingan Warga Binaan Pemasyarakatan.

Peraturan Pemerintah Nomor 32 Tahun 1999 tentang Syarat dan Tata Cara Pelaksanaan Hak Warga Binaan Pemasyarakatan.

Peraturan Pemerintah Nomor 57 Tahun 1999 tentang Kerjasama Penyelengaraan Pembinaan dan Pembimbingan Warga Binaan Pemasyarakatan. Peraturan Pemerintah RI No. 31 Tahun 1999,'Tentang Pembinaan dan Pembimbingan Warga Pemasyarakatan,"(Himpunan Peraturan Perundang-Undangan tentang Pemasyarakatan, Tahun 1999.

Peraturan Menteri Hukum dan Hak Asasi Manusia Republik Indonesia Nomor M.HHOT.02.02 Tahun 2009 tentang Cetak Biru Pembaharuan Pelaksanaan-Pelaksanaan Sistem Pemasyarakatan.

Keputusan Menteri Kehakinaman Republik Indonesia No: M.02-PK.04.10 Tahun 1990 tentang Pola Pembinaan Narapidana/Tahanan

Keputusan Direktur Jenderal Pemasyarakatan Nomor E.122.KP.10.10. tanggal 30 Oktober Tahun 1996 tentang Sepuluh Wajib Pemasyarakatan.
Keputusan Direktur Jenderal Pemasyarakatan Nomor E.22.PR.08.03. Tahun 2001 tentang Prosedur Tetap Pelaksanaan Tugas Pemasyarakatan.

Surat Keputusan Direktur Jenderal Pemasyarakatan Nomor E.273.PL.01.01 Tahun 1999 tentang 10 Program Strategis Direktorat Jenderal Pemasyarakatan (Renstra) Tahun 2000-2005.

\section{Buku:}

A. Widiada Gunakarya S.A. 1988. Sejarah dan Konsepsi Pemasyarakatan. Bandung: Armico.

Anwar, Yasmil dan Adang. 2010. Kriminologi. Bandung: Refika Aditama.

Bakir, Herman. 2007. Filsafat Hukum. Bandung: Refika Aditama.

Bungin, Burhan. 2001. Metodologi Penelitian Sosial. Surabaya: Airlangga.

Damian, Eddy.1968. Rulle of Law dan Praktek Penahanan di Indonesia. Bandung: Alumni.

Departemen Kehakiman dan HAM RI. 2000. Himpunan Peraturan Perundang-undangan tentang Pemasyarakatan Jilid 6. Jakarta.

Direktorat Jenderal Pemasyarakatan Departeman Kehakiman dan HAM RI. 2004. 40 Tahun Pemasyarakatan Mengukir Citra Profesionalisme. Jakarta.

Hamzah, Andi. 1985. Sistem Pidana dan Pemidanaan Indonesia dari Retribusi ke Reformasi. Jakarta: Pradnya Paramita.

Howard, John. 1972. The State of Prisons: DasarDasar Penologi, Usaha Pembaharuan Sistem Kependjaraan dan Pembinaan Narapidana. Disadur oleh Soedjono Dirdjosisworo. Bandung: Alumni.

Koentjaraningrat. 1981. Metode-metode Penelitian Masyarakat. Jakarta: Gramedia.

Muladi. 1995. Kapita Selekta Sistem Peradilan Pidana. Semarang: Badan Penerbit UNDIP.

Parang, Patta. 1997. "Peran Aktif Petugas Lembaga Pemasyarakatan dalam Membina Narapidana". Tesis Program Studi Ilmu Hukum Program Pasca Sarjana UI. Jakarta.

Petrus Irwan Penjahitan dan Wiwik Sri Widiarti. 2008. Pembaharuan Pemikiran, Dr. Sahardjo mengenai Pemasyarakatan Narpidana. Jakarta: Indhill.

Priyatno, Dwidja. 2006. Sistem Pelaksanaan Pidana Penjara di Indonesia. Bandung: Rafika Aditama. 
Rahardjo, Satjipto. 1983. Aneka Persoalan Hukum dan Masyarakat. Bandung: Alumni. , 1984. Sejarah dan Azaz-azaz Penologi (Pemasyarakatan). Bandung: Armico.

Sahetapy, J.E. 2005. Pisau Analisis Kriminologi. Surabaya: Citra Aditya Bakti.

Soekanto, Soerjono. 1977. Kesadaran Hukum dan Kepatuhan Hukum. Jakarta: Rajawali.

Soemadipraja dan Romli Atmasasmita. 1979. Sistem Pemasyarakatan di Indonesia. Bandung: Bina Cipta.

Soerjobroto, Baharudin. 1972. "Pelaksanaan Sistem Pemasyarakatan”. Majalah Pembinaan Hukum. Jakarta.
Sujatno, Adi. "Upaya-upaya Menuju Pelaksanaan Lembaga Pemasyarakatan Terbuka di Lembaga Pemasyarakatan Kelas I Jawa Timur". Makalah. Disampaikan pada Seminar Nasional Pemasyarakatan Terpidana II. Tanggal 8-9 Nopember 1993. Fakultas Hukum UI.

\section{Website:}

http://smslap.ditjenpas.go.id. diakses tanggal 22 Februari 2012.

Tribunews.Com. Jakarta. diakses tanggal 11 Juli 2013. Yulis Setiawan, Thibunews.com. diakses tanggal 3 Maret 2013.

, Antara news. diakses tanggal 22 Februari 2012. 